\title{
Serological and molecular techniques applied for identification of Plasmodium spp. in blood samples from nonhuman primates
}

Técnicas sorológicas e moleculares aplicadas na identificação de Plasmodium spp. em amostras de primatas não humanos

Mayra Araguaia Pereira Figueiredo ${ }^{1 *}$; Silvia Maria Di Santi ${ }^{2,3}$; Wilson Gómez Manrique $;$; Marcos Rogério André5; Rosangela Zacarias Machado 5

\footnotetext{
${ }^{1}$ Laboratório de Parasitologia Animal, Curso de Medicina Veterinária, Universidade Federal de Rondônia - UNIR, Rolim de Moura, RO, Brasil

${ }^{2}$ Centro de Estudos da Malária, Superintendência de Controle de Endemias - SUCEN, São Paulo, SP, Brasil

${ }^{3}$ Departamento de Saúde do Estado de São Paulo, Instituto de Medicina Tropical de Sáo Paulo - IMTSP, Universidade de São Paulo - USP, São Paulo, SP, Brasil

${ }^{4}$ Laboratório de Patologia Veterinária, Curso de Medicina Veterinária, Universidade Federal de Rondônia - UNIR, Rolim de Moura, RO, Brasil

${ }^{5}$ Laboratório de Imunoparasitologia, Faculdade de Ciências Agrárias e Veterinárias - FCAV, Universidade Estadual Paulista - UNESP, Jaboticabal, SP, Brasil
}

Received May 6, 2018

Accepted May 10, 2018

\begin{abstract}
The aim of this study was to identify Plasmodium spp. in blood samples from nonhuman primates (NHPs) in the state of Maranhão, using classical and alternative techniques for examination of human malaria. A total of 161 blood samples from NHPs were analyzed: 141 from captive animals at a Wildlife Screening Center (CETAS) and 20 from free-living animals in a private reserve. The techniques used were microscopy, rapid diagnostic test (RDT), Indirect fluorescent antibody test (IFAT) and molecular techniques (semi-nested PCR, quantitative real-time PCR and LAMP). Two serological methods (dot-ELISA and indirect ELISA) were also standardized with rhoptry protein-soluble antigen of P. falciparum and $P$. berghei. Trophozoite forms of Plasmodium sp. were identified on slides from five different animals. No samples were positive through RDT and LAMP. Four samples were seropositive for $P$. malariae through IFAT. The samples showed low reactivity to ELISA. Plasmodium sp. was detected in $34.16 \%(55 / 161)$ of the samples using qPCR based on the $18 \mathrm{~S}$ rRNA gene. After sequencing, two samples showed $100 \%$ identityl to $P$. malariae, one showed $97 \%$ identity to Plasmodium sp. ZOOBH and one showed $99 \%$ identity to $P$. falciparum. PCR was shown to be the most sensitive technique for diagnosing Plasmodium in NHP samples.
\end{abstract}

Keywords: Simian malaria, New World monkeys, Plasmodium brasilianum, Plasmodium malariae, 18S rRNA, zoonosis.

\section{Resumo}

Neste estudo objetivamos identificar Plasmodium spp. em amostras sangue de primatas não humanos (PNH) do estado do Maranhão, utilizando técnicas clássicas e alternativas para o exame da malária humana. Foram analisadas 161 amostras de sangue de PNH, sendo 141 de CETAS (cativeiro) e 20 de reserva particular (vida livre), utilizando microscopia, teste de diagnóstico rápido (RDT), imunofluorescência indireta (IFI) e técnicas moleculares (semi-nested PCR, PCR em tempo real quantitativo e LAMP). Dois métodos sorológicos (dot-ELISA e ELISA indireto) também foram padronizados com antígenos solúveis de roptrias de P. falciparum e P. berghei. Formas trofozoíticas de Plasmodium sp. foram identificadas em lâminas de cinco animais diferentes. Nenhuma amostra foi positiva em TDR e LAMP. Quatro amostras foram soropositivas

\footnotetext{
*Corresponding author: Mayra Araguaia Pereira Figueiredo. Laboratório de Parasitologia Animal, Curso de Medicina Veterinária, Departamento de Medicina Veterinária, Universidade Federal de Rondônia - UNIR, Av. Norte Sul, Nova Morada, 7300, Campus Rolim de Moura, CEP 76940-000, Rolim de Moura, RO, Brasil. e-mail: mayra.araguaia@unir.br
} 
para P. malariae na IFI. Os soros de PNH mostraram baixa reatividade pelo ELISA indireto. Plasmodium sp. foi detectado em 34,16\% (55/161) das amostras utilizando a qPCR baseada no gene $18 \mathrm{~S}$ rRNA. No sequenciamento, duas amostras mostraram identidade com P. malariae (100\%), uma com Plasmodium sp. ZOOBH (97\%) e uma com P. falciparum (99\%). A PCR mostrou ser a técnica mais sensível para diagnósticos de Plasmodium em amostras de PNH.

Palavras-chave: Malária simiana, macacos do Novo Mundo, Plasmodium brasilianum, Plasmodium malariae, $18 \mathrm{~S}$ rRNA, zoonoses.

\section{Introduction}

Malaria is one of the three most important infectious diseases in the world and is the parasitic disease accounting for the largest number of human deaths. The disease is caused by protozoan species of the genus Plasmodium and is transmitted by Anopheles mosquitoes in endemic areas, such as sub-Saharan Africa, Southeast Asia and northern Brazil (JOYNER et al., 2015; WHO, 2016). Four species of Plasmodium mainly infect humans (P. falciparum, $P$. vivax, $P$. malariae and $P$. ovale) and at least 26 species are known to infect non-human primates (NHPs) (AMERI, 2010).

For decades, NHPs have been used as an experimental model for studies on human malaria, both because they are phylogenetically close to humans and because they are sensitive to infection by Plasmodium species that infect humans, such as $P$. falciparum and P. vivax (JOYNER et al., 2015). In addition, NHPs are hosts of Plasmodium species that are genetically, morphologically and immunogenically similar to species that cause human malaria. For instance, P. brasilianum and P. simium, which affect New World primates and are identical to $P$. malariae and $P$. vivax, respectively, can naturally infect humans (DEANE, 1992; LALREMRUATA et al., 2015). Plasmodium brasilianum has been identified in several primate species of the Cebidae family (except Aotus) and, rarely, in specimens of Saguinus midas niger (Callitrichinae, in the taxonomic classification proposed by PERELMAN et al., 2011) in Central and South America (DEANE, 1964; FANDEUR et al., 2000; CHINCHILLA et al., 2006). On the other hand, P. simium has been reported in Alouatta fusca, Brachyteles arachnoides (DEANE, 1992) and Alouatta caraya (DUARTE et al., 2008), but restricted to the Atlantic Forest in southeastern and southern Brazil, in the states of Espírito Santo, São Paulo, Santa Catarina and Rio Grande do Sul (DEANE, 1969). Both species, P. brasilianum and P. simium, may reflect a recent occurrence of zooanthropoonosis, through lateral transmission of human Plasmodium species to New World primates (TAZI \& AYALA, 2011; LALREMRUATA et al., 2015; BRASIL et al., 2017). In a very recent study, P. simium was identified in humans living near the Atlantic Forest (BRASIL et al., 2017).

Over the last eighteen years, simian malaria has been an important threat in endemic countries, not only because of the constant proximity of urban and wild areas around the world, but also because of the frequency and high number of cases of human malaria due to $P$. knowlesi, a species of Plasmodium that is native to Macaca fascicularis in Southeast Asia. This species is considered to be the fifth source of human malaria (WILLIAM et al., 2013). Protocols for its detection have already been published (SINGH \& DANESHVAR, 2013). Simian malaria in the Americas is a complicating factor in diagnosing malaria in samples from humans living in forest areas or from ecotourism practitioners. This is mainly due to morphological similarity between Plasmodium species that infect humans and non-human primates (AMERI, 2010), and because there are no standard protocols for specific serological and molecular diagnoses.

Finding diagnostic methods of greater sensitivity has always been one of the most important concerns of researchers and practitioners working with malaria, since faster diagnosis is directly linked to treatment success (WHO, 2016). Traditionally, morphological diagnosis of human malaria is considered to be the gold standard, given the low cost of this technique, since the areas at risk generally lack the infrastructure for use of more modern techniques and the populations at risk do not receive public healthcare (BRASIL, 2005; WHO, 2015). The sensitivity of this technique under field conditions is up to 100 parasites per microliter of blood (MYJAK et al., 2002). However, reading the slides to accurately identify mixed infections is a laborious and often difficult process (RUBIO et al., 2002), especially with the ring stage trophozoite (AMERI, 2010; FIGUEIREDO et al., 2015).

RDT, which can be performed by any professional, has the capacity to detect one or more species of Plasmodium spp. in a blood sample and the result can be obtained in twenty minutes (WHO, 2009). However, its sensitivity is similar to that one commonly achieved by microscopy. Tests recommended by the World Health Organization (WHO) show 95\% sensitivity or 100 parasites/ $\mu \mathrm{L}$ for $P$. falciparum (WHO, 2004).

Serological tests for diagnosing malaria have been used since the 1960s. At that time, they constituted a breakthrough for diagnostic research (BRUCE-CHWATT, 1985). The serological test used as standard for detection of antibodies to Plasmodium spp. is the indirect fluorescent antibody test (IFAT) reaction. On the other hand, the ELISA test is applied for blood-group screening and in epidemiological studies (DODERER et al., 2007). In clinical practice, serological testing cannot be applied for diagnosing acute malaria (DRAPER \& SIRR, 1980). This limitation is due to the antibody production time, which may take one to two weeks after the initial infection and may only persist for three to six months (BRUCE-CHWATT, 1985; DODERER et al., 2007).

Molecular techniques have become popular in several fields of research, because of their sensitivity and specificity. In diagnosing human malaria, molecular techniques can be used as methods that are ancillary to microscopy, and for evaluating the performance of new diagnostic tests (CICERON et al., 1999). For diagnosing some species of simian malaria, the polymerase chain reaction (PCR) is considered to be the best technique, both because of its sensitivity, given that it can detect fewer than 5 parasites $/ \mu \mathrm{L}$ (GAMA et al., 2007), and because of its specificity (AMERI, 2010). The technique of isothermal amplification of DNA (loop-mediated isothermal amplification, LAMP) also has the advantages of high specificity and the possibility of implementing it in the field, without previous DNA extraction (PARIDA et al., 
2008). The technique identifies six target regions of a gene and uses an enzyme capable of displacing the DNA strand without the need for temperature changes (ZHANG et al., 2014).

For diagnosing simian malaria, diagnostic techniques for human malaria are often adapted to the particularities of this type of sample, so as to deal with the low levels of antibodies and the low degrees of parasitemia that are observed in natural infections due to Plasmodium spp. in New World primates In addition, these primates present chronic infections with low degrees of parasitemia (AMERI, 2010), independently of the primate species or of the biome that they inhabit (CHINCHILLA et al., 2006; FIGUEIREDO et al., 2015). Detection of Plasmodium spp. using accurate techniques is important in projects for reintroducing endangered species and for avoiding the risks of introduction of pathogens (AITKEN et al., 2016).
In the present study, we comparatively describe adaptations of techniques for diagnosing human malaria that were used to diagnose Plasmodium spp. in New World primates that were sampled on the island of São Luís, state of Maranhão, Brazil.

\section{Materials and Methods}

\section{Study site location and blood samples from NHPs}

The present study was conducted in two municipalities on the island of São Luís (Figure 1), in the state of Maranhão, in the northeast of Brazil. Between 2009 and 2014, blood samples were collected from NHPs (Table 1) that were being kept at the local Wildlife Screening Center (CETAS, according to its initials in Portuguese) ( $\mathrm{n}=141)\left(2^{\circ} 56^{\prime} 80^{\prime \prime} \mathrm{S} ; 44^{\circ} 21^{\prime} 01^{\prime \prime} \mathrm{W}\right)$ and from

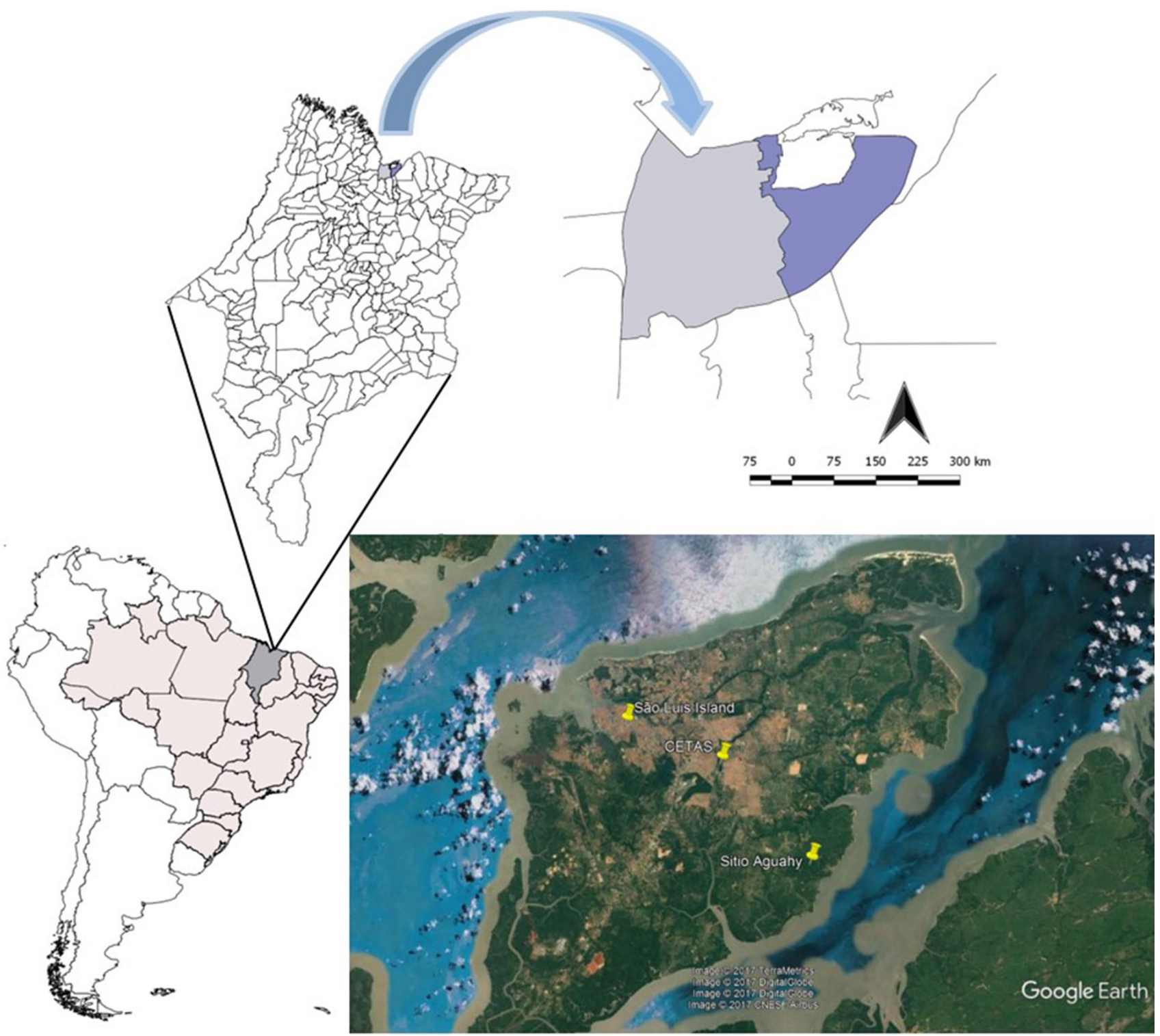

Figure 1. Map of South America highlighting Brazil and the state of Maranhão. Map of the Island of São Luís showing the division of the two municipalities (São Luís - light blue and São José de Ribamar - dark blue) of the Island of São Luís. Satellite image of the island of São Luís, where nonhuman primates blood samples were collected (CETAS and Sítio Aguahy). 
Table 1. Nonhuman primates species, common name (English and Portuguese), and local of capture.

\begin{tabular}{cccc}
\hline Species & Common name in English & Common name in Portuguese & Local of capture* \\
\hline Aotus infulatus & night monkey & Macaco-da-noite & CETAS \\
Chiropotes satanas & black bearded saki & Cuxiú & CETAS \\
Sapajus spp. & capuchin & Macaco-prego & CETAS (89) and Sítio Aguahy (17) \\
Callithrix jacchus & common marmoset & Sagui & CETAS \\
Saimiri sciureus & squirrel monkey & Capijuba & CETAS (21) and Sítio Aguahy (3) \\
Saguinus midas niger & black-handed tamarins & Soim & CETAS \\
\hline
\end{tabular}

*The number in parentheses indicates the numbers of primates sampled at each capture site.

free-living NHPs in the Sítio Aguahy Private Reserve $(\mathrm{n}=20)$ (2038'76” S; 4408'22” W). Blood samples were collected in tubes containing EDTA, for semi-nested PCR, rapid diagnostic test (RDT) and Loop-imediated isothermal amplification of DNA (LAMP), and in tubes without anticoagulant for serological tests (FIGUEIREDO et al., 2017).

The study was approved by the Ethics Committee for Animals Use of the School of Agrarian and Veterinary Sciences (FCAV), São Paulo State University (UNESP), Jaboticabal campus (Protocol no. 011.480/12) and by the Chico Mendes Institute for Biodiversity Conservation (ICMBio) (license no. 34.282-2).

\section{Microscopic examination}

Thin and thick blood films were prepared using blood from finger puncture, which was performed using a lancet on each animal. The thin blood films were fixed using methanol and stained with Giemsa (inverted slide) diluted in buffered water (check additional information) for 35 minutes. The thick blood films were pre-stained with buffered methylene blue for five seconds and then stained with Giemsa (Sigma-Aldrich, St. Louis, MO,USA) for seven minutes, as recommended by WHO (2005). The slides were examined by an experienced microscopist at the Center for Malaria Studies, Superintendency for Endemic Disease Control (SUCEN), in São Paulo, SP, Brazil.

\section{RDT: commercially-available rapid test}

The Plasmodium antigen-based RDT was performed on aliquots of hemolyzed whole blood from NHPs, using the "First-response Malaria Ag. pLDH/HRP2 Combo P.f. and PAN Detection Card Test" (Premier Medical Corporation Ltd, Kachigam, Nani Daman, India), in accordance with the manufacturer's recommendations. The reading was performed after 20 minutes.

\section{DNA extraction}

DNA was extracted from $200 \mu \mathrm{L}$ of whole blood from NHPs using the QIAamp DNA mini-kit (Qiagen ${ }^{\circledR}$, Valencia, CA, USA), in accordance with the manufacturer's recommendations, with a final elution volume of $50 \mu \mathrm{L}$. The DNA concentration and absorbance ratio $(260 / 280 \mathrm{~nm})$ were measured using spectrophotometer equipment $\left(\right.$ Nanodrop $^{\circledR}$, Thermo Scientific, Waltham, MA, USA).
Semi-nested multiplex PCR (snPCR) based on $18 S$ rRNA gene of Plasmodium spp.

In snPCR assays, the species-specific $18 \mathrm{~S}$ rRNA nucleotide sequences of $P$. falciparum, P. vivax, and P. malariae were amplified, as previously described by Rubio et al. (1999), with slight modifications. Using the primers PLF, UNR and HUF, two fragments were generated: one of $231 \mathrm{bp}$, of the mammalian endogenous gene (UNR-HUF); and another, ranging from 783 to $821 \mathrm{bp}$, of Plasmodium sp. (UNR-PLF) in the first reaction. The reaction mixture had a final volume of $25 \mu \mathrm{L}$ and contained 10X PCR buffer, $2.5 \mathrm{mM}$ of $\mathrm{MgCl}_{2}, 0.1 \mathrm{mM}$ of a mixture of deoxynucleotide triphosphates, $0.5 \mu \mathrm{M}$ of PLF and of UNR, $0.04 \mu \mathrm{M}$ of HUF, $1.25 \mathrm{U}$ of Taq platinum DNA polymerase (Life Technologies ${ }^{\circledR}$, Carlsbad, CA, USA) and $5 \mu \mathrm{L}$ of DNA. In all the reactions, ultra-pure water (Invitrogen ${ }^{\circledR}$, Carlsbad, CA, USA) was used as a negative control. Plasmodium vivax and $P$. malariae DNA samples from human infected patients (HRISTOV et al., 2014; LIMA et al., 2016) and P. falciparum DNA (strains K1 and Palo Alto obtained through in vitro culturing) were used as positive controls. The products were then subjected to a second reaction, using $2 \mu \mathrm{L}$ of the amplified product from the first reaction, in a final reaction volume of $25 \mu \mathrm{L}$, containing $1 \mathrm{X}$ Taq buffer, $2.5 \mathrm{mM}$ of $\mathrm{MgCl}_{2}, 0.1 \mathrm{mM}$ of deoxynucleotide triphosphate mixture, $0.5 \mu \mathrm{M}$ of PLF, $0.064 \mu \mathrm{M}$ of MAR, $0.3 \mu \mathrm{M}$ of FAR, $0.05 \mu \mathrm{M}$ of VIR and $1.25 \mathrm{U}$ of Taq DNA polymerase.

Plasmodium species were identified through sequencing the amplified products from the second reaction using a genus-specific protocol described by Santos et al. (2009) and Singh et al. (1999), based on the $18 \mathrm{~S}$ rRNA gene. The 240 bp products were viewed by means of electrophoresis on $2 \%$ agarose gel under UV light and were purified using Silica Bead DNA Gel Extraction kit (Thermo Scientific, Waltham, MA, USA), following the manufacturer's instructions. The nucleotide sequences obtained from each sample were compared with sequences previously deposited in the GenBank database, using the BLASTn software (ALTSCHUL et al., 1990).

Real-time PCR (qPCR) assay for Plasmodium sp. based on $18 S$ rRNA gene

\section{Construction of plasmid standards containing Plasmodium sp. 18S rRNA gene fragments}

Plasmodium falciparum and P. malariae (HRISTOV et al., 2014; LIMA et al., 2016) 18S rRNA gene fragments were amplified in conventional PCR assays using the same set of primers that are 
used in qPCR assays (GAMA et al., 2007). The amplification reactions were performed in a T100 thermal cycler (Bio Rad), using $4 \mu \mathrm{L}$ of DNA in a $46 \mu \mathrm{L}$ mixture, containing $1 \mathrm{X}$ PCR buffer, $2 \mathrm{mM}$ of $\mathrm{MgCl}_{2}, 1.25 \mathrm{U}$ of Taq Platinum DNA Polymerase (Life Technologies $^{\circledR}$, Carlsbad, CA, USA), $200 \mu \mathrm{M}$ of each dNTP and $200 \mathrm{nM}$ of each M60 and M61 primer. The thermal cycler was set with an initial hold $\left(95^{\circ} \mathrm{C} / 10\right.$ minutes) followed by 32 cycles (94 ${ }^{\circ} \mathrm{C} / 30$ seconds, $60{ }^{\circ} \mathrm{C} / 30$ seconds and $72{ }^{\circ} \mathrm{C} / 30$ seconds). The 84 bp amplicon was viewed by means of electrophoresis on $2 \%$ ethidium bromide-stained agarose gel. The products were purified using Silica Bead DNA Gel Extraction kit (Thermo Scientific, Waltham, MA, USA) and were quantified in a spectrophotometer (Nanodrop, Thermo Scientific, Dubuque, Illinois, USA) for in-house preparation of plasmids. Cloning of the purified products was carried out in the pGEM-T Easy Vector system (Promega, Madison, Wisconsin, USA), as recommended by the manufacturer. The ligation products were transformed into Escherichia coli One Shot Match $1^{\mathrm{TM}}$ chemically competent cells (Invitrogen, Carlsbad, CA, USA). The resulting clones were subjected to blue/white colony screening. The plasmid DNA was extracted using the QIAprep Miniprep kit (Qiagen, Valencia, CA, USA). In order to assess the detection limit of the TaqMan assay, standard curves were constructed using plasmid serial dilutions $\left(10^{5}, 10^{4}, 10^{3}, 10^{2}, 10^{1}\right.$ and $\left.10^{\circ}\right)$. The amplification efficiency (E) of each assay was calculated using the formula $\mathrm{E}=10^{-1} / \mathrm{slope}$. The number of copies of plasmids was determined in accordance with the following formula: $(\mathrm{Xg} / \mu \mathrm{L} \mathrm{DNA} /[$ plasmid length in bp $\times 660]) \times 6.022 \times 10^{23} \times$ plasmid copies $/ \mu \mathrm{L}$.

\section{qPCR assays}

The qPCR assays for detection of the Plasmodium sp. based on $18 \mathrm{~S}$ rRNA gene were performed as previously described by Gama et al. (2007), with slight modifications. All samples were tested in duplicate. The qPCR assays were performed in a final volume of $25 \mu \mathrm{L}$, containing $12.5 \mu \mathrm{L}$ of $1 \mathrm{X}$ TaqMan Universal Master Mix ${ }^{\circledR}$ (Life Technologies), $0.5 \mu \mathrm{M}$ of the primers M60 (5' ACAT GGC TAT GAC GGG TAA CG 3') and M61 (5' TGC CTT CCT TAG ATG TGG TAG CTA 3'), $0.3 \mu \mathrm{M}$ of the hydrolysis probe M62 (5' FAM - TCA GGC TCC CTC TCC GGA ATC GA-TAMRA $3^{\prime}$ ), and $5 \mu \mathrm{L}$ of DNA. The amplification conditions were $50{ }^{\circ} \mathrm{C} / 2$ minutes, $95^{\circ} \mathrm{C} / 10$ minutes and 40 cycles of $94^{\circ} \mathrm{C}$ for 30 seconds and $60{ }^{\circ} \mathrm{C}$ for 1 minute.

Amplification and qPCR measurements were performed using the CFX96 thermal cycler (Bio Rad, Hercules, CA, USA). All the analyses, including setting of the threshold and the quantification cycle $(\mathrm{Cq})$ values, were automatically established using the default settings. Assays were performed in 96-well plates, Low-Profile Multiplate $^{\mathrm{TM}}$ unskirted PCR plates (BioRad, Hercules, CA, USA).

\section{Loop-mediated isothermal amplification (LAMP) assay for Plasmodium sp. based on $18 S \mathrm{rRNA}$ gene}

The LAMP assay was carried out using the Loopamp ${ }^{\circledR}$ DNA kit (Eiken Chemical Co. Ltd, Japan), in accordance with Han et al. (2007). It used a set of genus-specific primers and was performed on 13 blood samples from NHPs that had previously been screened for Plasmodium by means of qPCR and cPCR assays. The final reaction volume of $25 \mu \mathrm{L}$, in Low-Profile Multiplate unskirted PCR plates (BioRad, Hercules, CA, USA), contained $1.6 \mu \mathrm{M}$ of the FIB (5' TCG AAC TCT AAT TCC CCG TTA CCT ATC AGC TTT TGA TGT TAG GGT 3') and BIP (5' CGG AGA GGG AGC CTG AGA AAT AGA ATT GGG TAA TTT ACG CG $3^{\prime}$ ) primers, $0.2 \mu \mathrm{M}$ of the F3 (5' GTA TCA ATC GAG TTT CTG ACC 3') and B3 (5' CTT GTC ACT ACC TCT CTT CT $3^{\prime}$ ) primers, $0.8 \mu \mathrm{M}$ of the LFP (5' CGT CAT AGC CAT GTT AGG CC 3') and LPB (5' AGC TAC CAC ATC TAA GGA AGG CAG $\left.3^{\prime}\right)$ primers, $1 \mu \mathrm{L}$ of Syto $9(125 \mu \mathrm{M})$ (Life Technologies $\left.{ }^{\circledR}\right)$, $2 \mathrm{X}$ reaction buffer $(12.5 \mu \mathrm{L}), 1 \mu \mathrm{L}$ of Bst DNA polymerase (Biolabs, Ipswich, MA, USA), and $2 \mu \mathrm{L}$ of DNA template.

The reactions were performed at $60^{\circ} \mathrm{C}$ for 100 minutes, followed by inactivation of the enzyme at $80^{\circ} \mathrm{C}$ for 2 minutes in a CFX 96 thermal cycler (BioRad, Hercules, CA, USA). The dissociation curve was performed at $60-96{ }^{\circ} \mathrm{C}$, with an increase of $0.5^{\circ} \mathrm{C}$ every 0.5 seconds.

\section{Serological techniques}

\section{Indirect Fluorescent Antibody Test (IFAT)}

IFAT was performed using the antigen from crude human erythrocyte infected with schizonts of $P$. malariae (HRISTOV et al., 2014) and $P$. falciparum (K1 and Palo Alto strains), obtained from in vitro cultures. Plasmodium berghei ANKA antigen was obtained from red cells from BALB/c experimentally infected mice. All the NHP serum samples were tested for the presence of anti-P. falciparum and anti-P. berghei IgG antibodies. However, due to the difficulty in obtaining blood samples from human patients infected with $P$. malariae, only ten NHP serum samples that were positive in the snPCR assays were tested for the presence of anti-P. malariae antibodies. Samples were classified as positive at a serum dilution of 1:20. Human serum samples, kindly supplied by SUCEN, were used as negative and positive controls in all the assays. Briefly, $10 \mu \mathrm{L}$ of the test and control serum samples diluted in phosphate buffered saline (PBS pH 7.2, check additional information) were deposited in each well and incubated at $37^{\circ} \mathrm{C}$ for 30 minutes in a humidity chamber. The slides were washed three times in PBS ( $\mathrm{pH} 7.2)$ for five minutes each. They were dried at room temperature and $10 \mu \mathrm{L}$ of anti-monkey IgG FITC-conjugation (SigmaAldrich $^{\circledR}$, St. Louis, MO, USA), diluted in accordance with the manufacturer's instructions (check additional information), were added into the wells containing NHP serum samples. Similarly, $10 \mu \mathrm{L}$ of anti-human IgG FITC (Sigma-Aldrich ${ }^{\circledR}$, St. Louis, MO, USA) was added into the wells containing human positive and negative control serum samples. Following this, the slides were incubated, washed and dried as described above. The slides were mounted in buffered glycerin ( $\mathrm{pH}$ 9.6, check additional information) and evaluated under an ultraviolet light emission microscope (Olympus, BX-FLA). 


\section{ELISA and dot-ELISA}

Preparation of rhoptry protein-soluble antigen from $P$. falciparum and $P$. berghei for ELISA and dot-ELISA tests

$\mathrm{K} 1$ and Palo Alto isolates of $P$. falciparum were cultured in vitro in $\mathrm{O}^{+}$red blood cells, using Petri dishes and RPMI 1640 medium (Sigma-Aldrich, St. Louis, MO, USA). The medium was supplemented with $10 \%$ type $\mathrm{B}^{+}$or $\mathrm{AB}^{+}$human plasma, as described by Trager \& Jensen (1976). The antigen was prepared from a P. falciparum culture with $10 \%$ parasitemia, where merozoites were the predominant form.

Two passages were made with the $P$. berghei ANKA strain in six-week-old female BALB/c-SPF mice (specific pathogen-free). The first intraperitoneal passage in mice was performed using $0.25 \mathrm{~mL}$ of parasitized erythrocytes, containing merozoites as the predominant form and presenting four-cross parasitemia. The second passage was performed four days after the first infection, using $0.1 \mathrm{~mL}$ of parasitized blood. Harvesting was performed eight days post-infection by means of intracardiac puncture.

The rhoptry-soluble antigens from $P$. berghei and P. falciparum were prepared in accordance with Machado et al. (1993), with modifications. The parasitized erythrocytes were centrifuged at 3,000 rpm for 15 minutes at $4{ }^{\circ} \mathrm{C}$, and the supernatant was discarded. Infected red blood cells were washed twice, using phosphate-buffered saline (PBS, pH 7.2). The precipitate was resuspended with ten times the volume of $83 \%$ ammonium tris-chloride (check additional information), warmed at $37{ }^{\circ} \mathrm{C}$. The tube containing the solution was inverted ten times and allowed to stand for five minutes at room temperature $\left(25^{\circ} \mathrm{C}\right)$. It was then centrifuged at $12,000 \mathrm{rpm}$ for 20 minutes at $4^{\circ} \mathrm{C}$, and the supernatant was discarded. The precipitate was resuspended in $5 \mathrm{~mL}$ of homogenization medium ( $\mathrm{pH} 7.5)$.

Following this, the solution was subjected to seven cycles of freezing and thawing in liquid nitrogen and in a water bath at $37^{\circ} \mathrm{C}$, respectively. The suspension was centrifuged at $500 \mathrm{rpm}$ for 10 minutes at $4^{\circ} \mathrm{C}$. The supernatant was kept and the precipitate was discarded. The supernatant was centrifuged at 12,000 rpm for 10 minutes at $4{ }^{\circ} \mathrm{C}$, and the precipitate was kept. In tubes that were specific for a Beckman ${ }^{\circledR}$ ultracentrifuge, a layered was prepared using $0.5 \mathrm{~mL}$ of $1.8 \mathrm{M}$ sucrose. In another tube, using the Econo Pump apparatus (Bio Rad) at the rate of $15 \mathrm{~mL} /$ minute, a mixture of $1 \mathrm{M}$ and $1.6 \mathrm{M}$ sucrose solutions was deposited in equivalent volumes. Then the precipitate (organellar fraction) was added, gently, down the inside of the wall of the tube, to avoid mixing with the sucrose medium. Centrifugation in a Beckman Optima "' LE-80K ultracentrifuge (Beckman, Illinois, USA) at $27,000 \mathrm{rpm}$ for 15 hours at $4{ }^{\circ} \mathrm{C}$ was performed. At the end, the fraction containing the rhoptry proteins was withdrawn. Four milliliters of homogenization medium were added into the tube. Centrifugation in a Beckman ultracentrifuge at 28,000 rpm for one hour at $4{ }^{\circ} \mathrm{C}$ was performed.

The precipitate was resuspended in $1 \mathrm{~mL}$ of homogenization medium (check additional information) and was frozen at $-20{ }^{\circ} \mathrm{C}$ until quantification. The protein content of the soluble antigen was determined by means of the bicinchoninic acid method, using the BCA reagent kit (Pierce Chemical Company), in accordance with the manufacturer's recommendations.

Visibility of $P$. falciparum and $P$. berghei rhoptry protein-soluble antigen in polyacrylamide gel (SDS-PAGE) and Western blotting

The soluble antigen obtained from rhoptry proteins was viewed by means of electrophoresis on polyacrylamide gel under denaturing conditions (LAEMMLI, 1970) and by means of Western blotting (TOWBIN et al., 1979). Incubations were performed using control human serum that was $P$. falciparum-positive, for antigens of both $P$. falciparum and $P$. berghei (for more information, see FIGUEIREDO, 2015).

Reactivity of the rhoptry protein-soluble antigen of $P$. falciparum and $P$. berghei by dot-ELISA

Rhoptry protein-soluble antigens of $P$. falciparum and $P$. berghei were used as antigens in the dot-ELISA technique to verify their ability to react with specific antibodies that were present in human serum samples that were positive for $P$. vivax (one year after cure), $P$. falciparum, $P$. vivax and $P$. malariae and in BALB/c mouse serum samples that had been experimentally infected with P. berghei. The technique was performed as previously described by Machado et al. (1993), with modifications.

Briefly, nitrocellulose discs were cut $(0.45 \mu \mathrm{m})$ and distributed in wells of a bottom plate. Then, $2 \mu \mathrm{g}$ of the antigens were deposited on each disk ( $P$. falciparum and $P$. berghei-soluble rhoptry proteins after standardization).

They were then dried at room temperature and blocked for 12 hours at $4{ }^{\circ} \mathrm{C}$ with $300 \mu \mathrm{L}$ of TBS buffer plus $5 \%$ skimmed milk powder. Control serum samples were diluted 1:50 and 1:100 in TBS-Tween 20 containing 5\% skimmed milk powder, and were incubated for 120 minutes at room temperature under constant stirring. The disks were then washed twice with TBS-Tween 20 plus 5\% skimmed milk powder and once with TBS-Tween 20 without skimmed milk powder (five-minute intervals between each wash).

Alkaline phosphatase-coupled anti-mouse conjugate (Sigma A-3562), diluted 1:30,000 in TBS-Tween 20 plus 5\% skimmed milk powder was added to each mouse serum well. For human serum samples, an alkaline phosphatase-coupled anti-human conjugate (Sigma A-1543) diluted 1:4,000 was used. After one hour of incubation, the reaction was developed by means of addition of the enzyme substrate 5-bromo-4-chloro-3-indoly phosphate and nitroethanol blue chloride, supplied through an alkaline phosphatase conjugate substrate kit (Bio-Rad), in accordance with the manufacturer's instructions.

The antigen dilution that presented the best-defined visual difference between positive and negative serum samples was considered to be the best result for the purposes of standardization. 


\section{Reactivity of $P$. falciparum and $P$. berghei rhoptry protein-soluble antigen through ELISA}

Initially, a block titration was performed using four human serum samples that were positive and four that were negative for $P$. falciparum, $P$. malariae and $P$. vivax (two samples), against the P. falciparum rhoptry antigen; three human control samples that were positive and three that were negative for $P$. falciparum, $P$. malariae and $P$. vivax; and one control mouse serum sample that was positive and one that was negative for $P$. berghei, against $P$. berghe $i$ antigen. The serum samples were assayed in duplicates at dilutions of 1:50, 1:100, 1:200, 1:400, 1:800 and 1:1600 in Maxisorp (Nunclon ${ }^{\circledR}$ Surface, Nunc, Denmark) flat-bottom microplate. These were tested against $P$. falciparum and $P$. berghei antigens diluted in carbonate-bicarbonate buffer (0.05 M; pH 9.6) at concentrations of $1.5 \mu \mathrm{g} / \mathrm{mL}, 2.5 \mu \mathrm{g} / \mathrm{mL}, 5.0 \mu \mathrm{g} / \mathrm{mL}$ and $10.0 \mu \mathrm{g} / \mathrm{mL}$. After defining the optimal assay concentrations, the serum samples from Neotropical primates were tested.

The plates were incubated at $4^{\circ} \mathrm{C}$ with $100 \mu \mathrm{L}$ of the soluble antigen diluted at the optimum concentration of $2.5 \mu \mathrm{g} / \mathrm{mL}$, for 12 hours. The plates were then washed with PBS-Tween 20 and incubated with $5 \%$ milk powder blocker at $37^{\circ} \mathrm{C}$ for two hours. The plates were washed again with PBS-Tween 20 . Then, $100 \mu \mathrm{L}$ (1:100) of the diluted test serum samples and the positive and negative reference serum samples were added again.

Afterwards, the serum samples were incubated at $37^{\circ} \mathrm{C}$ for 1.5 hour and were washed as previously described. One hundred microliters of anti-monkey IgG conjugate (Sigma-Aldrich ${ }^{\circledR}$, St. Louis, MO, USA) (NHP serum samples), anti-human IgG conjugate (Sigma-Aldrich ${ }^{\circledR}$, St. Louis, MO, USA) (controls) and anti-mouse IgG conjugate (mouse serum sample) (Sigma Aldrich $^{\circledR}$, St. Louis, MO, USA), all diluted in PBS-Tween 20 plus 5\% skimmed milk powder, were deposited in each well of microplates, followed by further incubation and washing. Finally, $100 \mu \mathrm{L}$ of para-nitrophenyl phosphate substrate (diluted $1 \mathrm{mg} / \mathrm{mL}$ in diethanolamine buffer, $\mathrm{pH}$ 9.8; Sigma N-9389) was added in each well of microplates, followed by incubation for 45 minutes at room temperature. After this period, absorbance values were read at $405 \mathrm{~nm}$ in an automatic ELISA microplate reader (MRX TC Plus, Dynex Technology).

\section{Results}

\section{Microscopy}

In total, 161 thick blood films and 161 thin blood films were prepared. Plasmodium sp. trophozoites were observed in erythrocytes from five NHPs (four individuals of Sapajus spp. and one of Callithrix jacchus) sampled at CETAS, São Luís, Maranhão, Brazil (Figure 2).

\section{$R D T$}

None of the samples were positive in the RDT test. On the other hand, none of the tests were invalid, since the positive control zone appeared in all tests.

\section{Molecular diagnosis}

snPCR

In the first snPCR reaction, 29.81\% (48/161) of the NHP samples were positive (Figure 3), comprising 10 free-living animals captured at the Sítio Aguahy (São José de Ribamar) (20.8\%) and 38 monkeys that were being kept at CETAS in São Luís (79.2\%).

Regarding the species-specific diagnosis, 47 samples from NHPs (47/48) were positive for P. brasilianum/P. malariae, among which eight were from free-living NHPs that were caught at Sítio

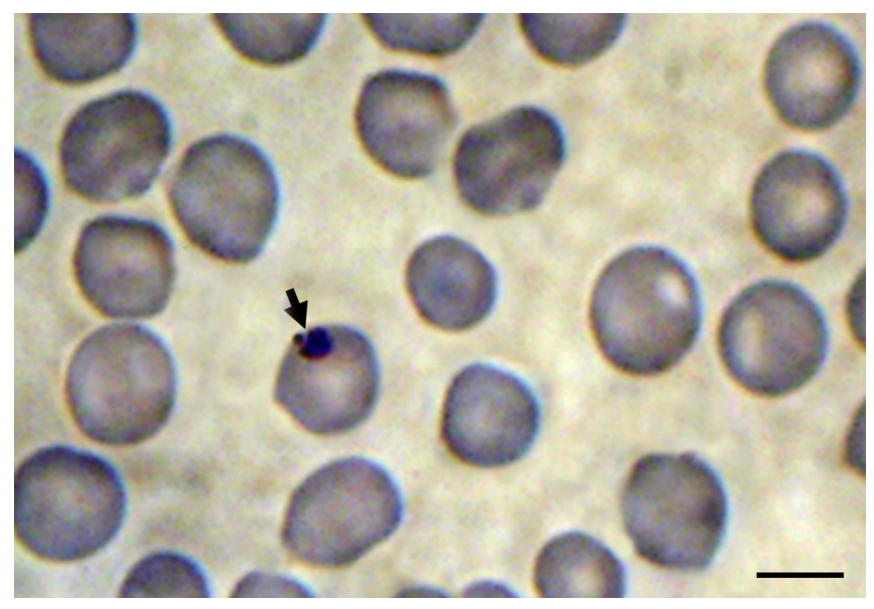

Figure 2. Photomicrographs of Plasmodium sp. visualized by light microscopy in thin Giemsa-stained blood smears from a male specimen of Sapajus sp. Bar $=10 \mu \mathrm{m}$.
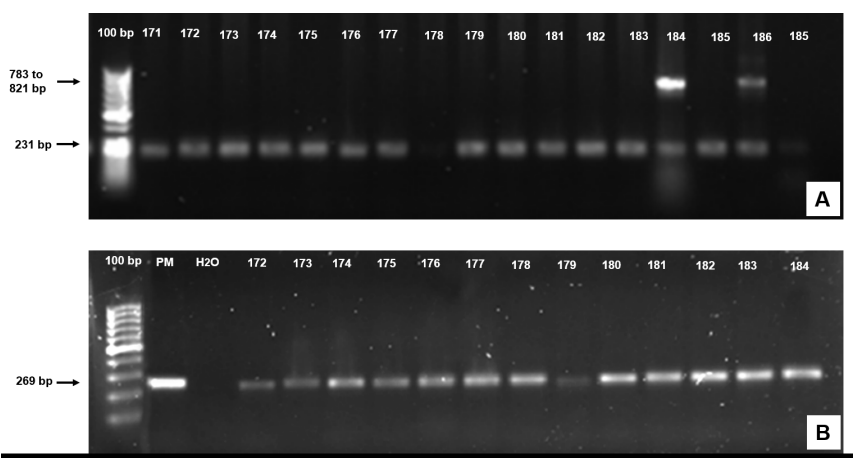

Figure 3. Genus-specific and species-specific detection of species of human malaria in monkeys sample in two municipalities of the Island of São Luís by PCR with $18 \mathrm{~S}$ rRNA gene as described by Rubio et al. (1999). (A) amplified products from the first snPCR reaction, in which a $231 \mathrm{bp}$ fragment from the endogenous gene can be visualized and gender-specific fragment from 783 to $821 \mathrm{bp}$ that identifies positivity for Plasmodium (size varies according to species of Plasmodium). A molecular weight marker of 100 bp (Invitrogen ${ }^{\circledR}$ ) (first channel) was used; (B) amplified products of the second species-specific reaction of snPCR for the species P. malariae (269 bp), P. vivax (499 bp) and P. falciparum (395 bp). Positive control of $P$. malariae (PM), negative control (ultra-pure sterilized $\mathrm{H}_{2} \mathrm{O}$ ), followed by positive samples (172-178) of Sapajus sp. (Sítio Aguahy) and (179-184) Sapajus sp. (CETAS do São Luís), respectively. 
Aguahy. NHP samples showing Plasmodium trophozoites in blood smear examinations were negative in snPCR assays.

Unfortunately, almost all the positive samples yielded weak intensity bands, thus precluding sequencing. After sequencing and BLAST analysis on four amplicons, the Plasmodium sp. sequences (18 rRNA gene) detected in two specimens of Sapajus sp. (\#136 and \#156 of CETAS) showed 100\% identity to P. malariae (GU950655) and to Plasmodium malariae isolate Oumu (AB489196.1), respectively. The Plasmodium sp. sequence detected in a specimen of Sapajus sp. (\#137 from CETAS) showed 97\% identity to Plasmodium ZOOBH (EF090276), previously detected in a Psittacidae specimen. The Plasmodium sp. sequence detected in a specimen of Sapajus sp. (\#145 from CETAS) showed 99\% identity to P. falciparum (M19173). The nucleotide sequences generated from each sample (sense and anti-sense) were smaller than $200 \mathrm{bp}$, precluding its deposit in GenBank database.

\section{LAMP}

None of the 13 samples tested produced amplification. All controls functioned including the plasmids in base 10 dilutions (Figure 4).

\section{$q P C R$}

Out of the 161 samples tested through qPCR, 34.16\% (55/161) were positive: seven (7/55) (12.72\%) from free-living NHPs (Sítio Aguahy, São José de Ribamar) and 48 (87.28\%) from animals kept at CETAS, São Luís (Figure 5).

\section{Serological tests}

\section{IFAT}

Four out of the ten samples tested for $P$. malariae were positive at 1:20 dilutions (Figure 6). None of the 151 serum samples tested against $P$. falciparum and $P$. berghei antigens were shown to be positive.

\section{SDS-PAGE and Western blotting}

In a small-scale test, it was possible to verify separation of the major proteins in $P$. falciparum and $P$. berghei rhoptries of higher molecular weight. Confirmation of the separation of these proteins could be seen through SDS-PAGE gel and Western
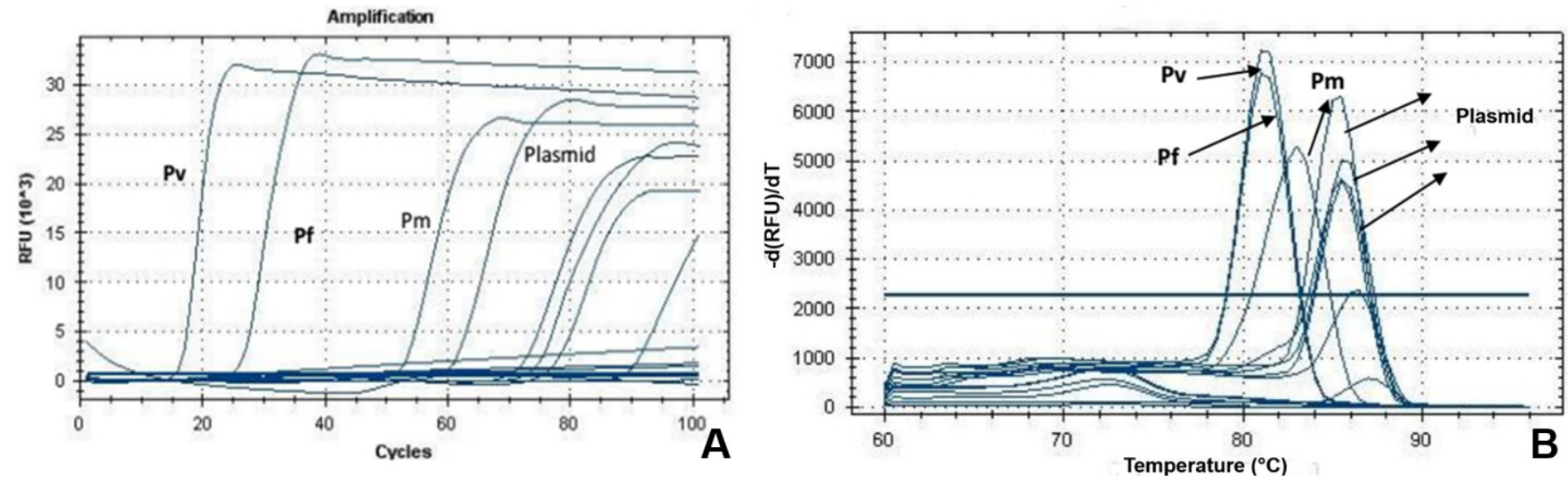

Figure 4. (A) Amplification curve of Plasmodium spp. by the LAMP technique, using positive controls for P. vivax (Pv), P. malariae (Pm) and P. falciparum (Pf) and plasmid constructed from gene 18S rRNA of P. falciparum DNA fragment (84 bp), diluted in base 10; (B) Dissociation curves showing the different peaks of Plasmodium species positive controls and plasmid.
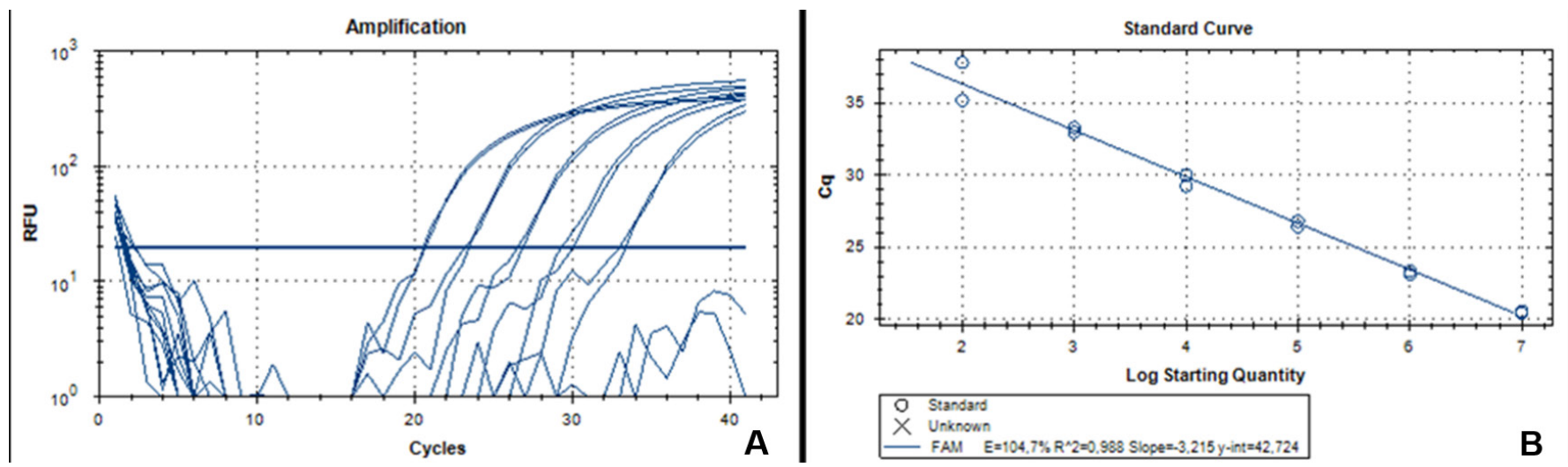

Figure 5. Amplification and standard curves of the qPCR assay based on an $18 \mathrm{~S}$ rRNA 84 bp fragment. (A) Cycles of amplification of the 84 bp plasmid at base 10 dilutions; (B) Standard curve developed from base 10 dilutions of the plasmids. This curve displayed an amplification efficiency of $104.7 \%$ and a determination coefficient $\left(R^{2}\right)$ of 0.98 . 
blotting (Figure 7), using positive (human and mouse) control serum samples.

\section{Dot-ELISA and ELISA}

Human serum samples that were positive for $P$. falciparum, $P$. vivax and $P$. malariae, samples from patients cured of $P$. vivax (one year earlier), and mouse serum samples (positive for P. berghei) showed good reactivity through the dot-ELISA technique against P. falciparum antigens. However, these human serum samples showed low reactivity against $P$. berghei antigens. Both $P$. falciparum and $P$. berghei antigens showed good discrimination between negative and positive control serum samples (Figure 8).

Human serum samples positive for $P$. falciparum, $P$. vivax and $P$. malariae, and mouse serum samples positive for $P$. berghei showed low reactivity in the indirect ELISA-test. The optimum

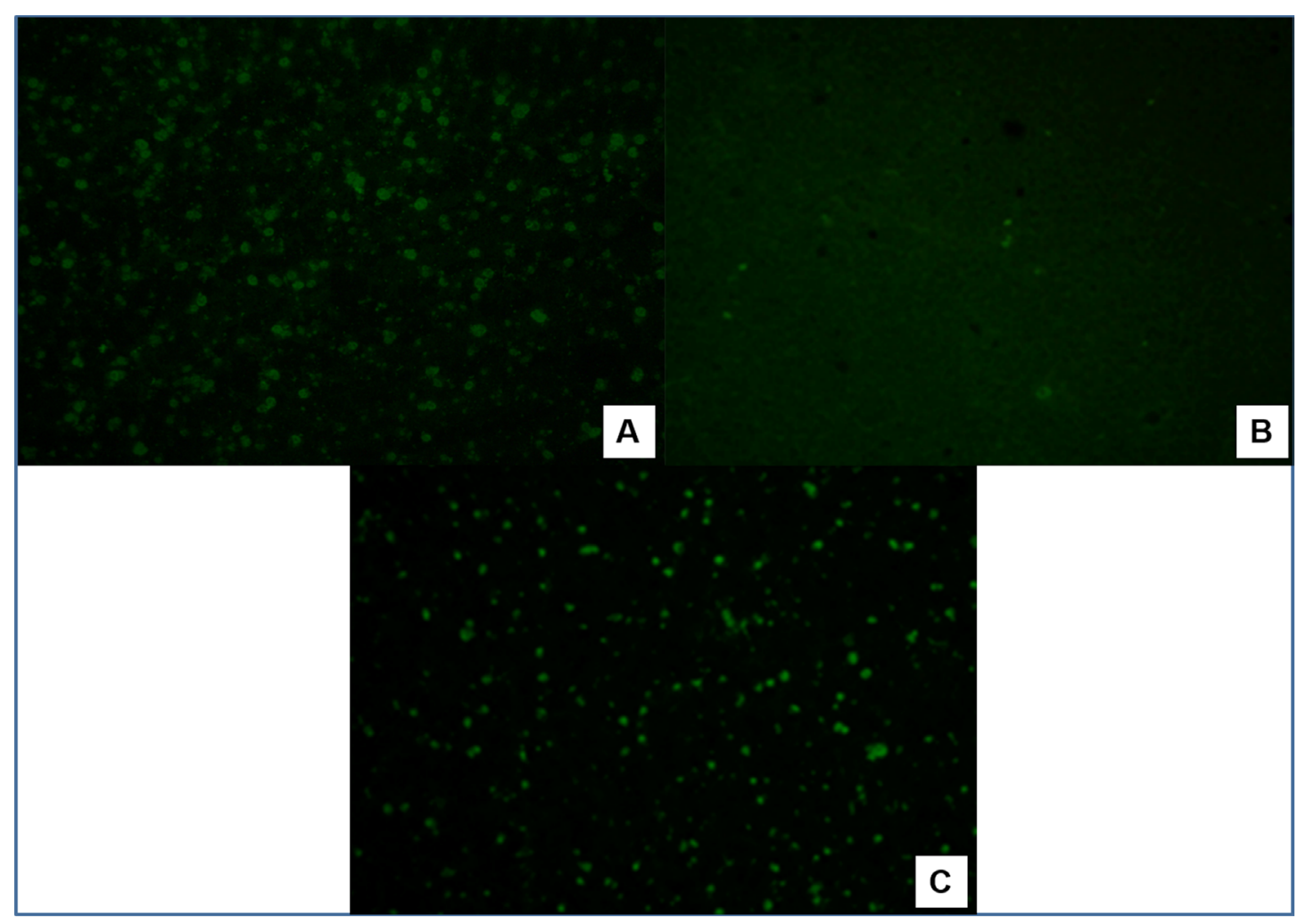

Figure 6. Photomicrography of the IFAT assay for IgG antibodies against $P$. malariae: (A) positive human control serum; (B) negative human control serum; (C) Sapajus sp. male specimen positive sample tested at the 1:20 dilution of (CETAS of São Luís).

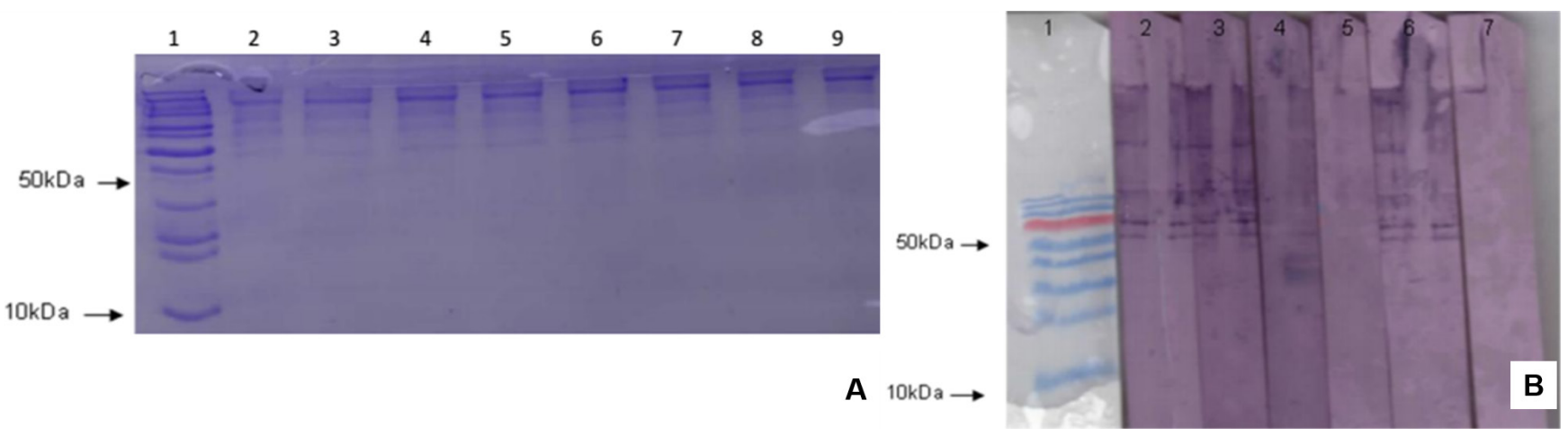

Figure 7. (A) polyacrylamide gel electrophoresis 12\% (SDS-PAGE), stained with Comassie Briliant Blue R-250, from rhoptries proteins of P. falciparum culture and of inoculation in BALB/c mice with $P$. berghei strain. Used on the line 1 molecular weight marker Unstained Protein (Thermo Scientific), followed (2 to 5) fractions of $P$. falciparum and $P$. berghei (6 to 9 ). The gels were kept in distilled water. The molecular weight of the rotor proteins vary from $40 \mathrm{kDa}$ to $240 \mathrm{kDa}$ (SAM-YELLOWE, 1996); (B) visibility of the fractions of rhoptry protein $P$. berghei nitrocellulose membrane by Western blotting after membrane incubation with human serum samples, positive and negative controls for P. falciparum. Prestained Protein (Thermo Scientific), followed by human serum positive for $P$. falciparum at the dilutions of 1:20 (line 2), 1:50 (line 4) and 1: 100 (line 6); negative human serum for Plasmodium spp. At 1:20 dilutions (line 3); 1:50 (line 5) and 1: 100 (line 7). 


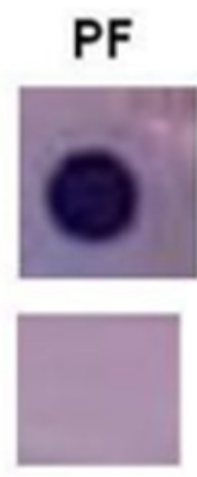

1

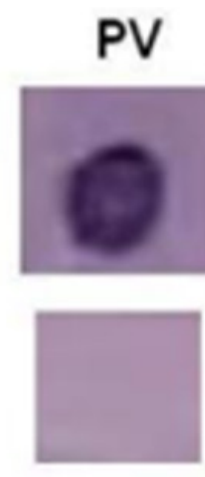

2
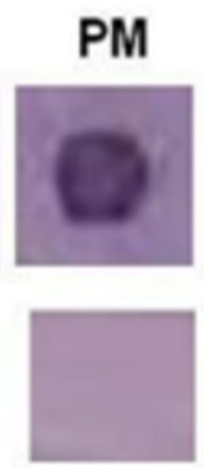

3

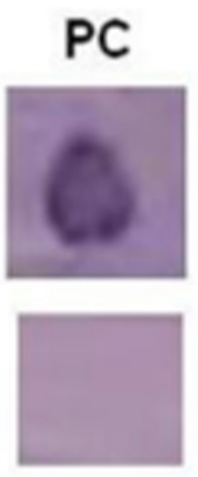

4 A

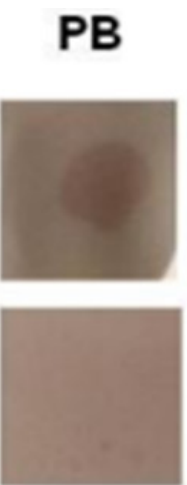

C
PF
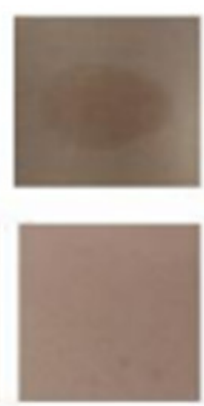

1
PV
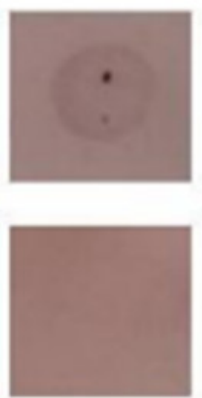

2
PM
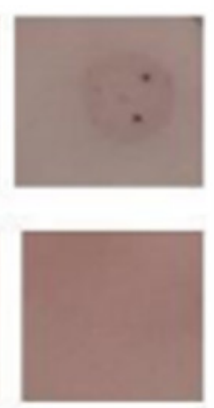

3

Figure 8. Photograph of the reactivity of the soluble antigens of with human and mouse sera samples in nitrocellulose membranes by the Dot-ELISA technique at the dilution 1:100. (A) reactivity between the P. falciparum rhoptries protein antigen and the human positive samples from P. falciparum (PF), P. vivax (PV), P. malariae (PM) and patient serum cured P. vivax one year ago (PC), human sera negative for Plasmodium spp. $(1,2,3$ and 4); (B) reactivity between the $P$. berghei rhoptries antigen of $P$. berghei and the mouse serum infected with $P$. berghei (PB) and human sera positive for PF, PV and PM, respectively, and negative mouse serum (C), followed by negative human sera (1, 2 and 3).

concentration of soluble $P$. falciparum and $P$. berghei rhoptry proteins was $2.5 \mu \mathrm{g} / \mathrm{mL}$ and the optimum serum dilution was 1:100.

\section{Comparison of results obtained by morphological, serological and molecular techniques for Plasmodium spp.}

Five NHP blood samples (\#1, \#5, \#17, \#18 and \#19) showing evolutionary forms of Plasmodium sp. were also positive in qPCR assays. No anti-Plasmodium spp. antibodies were detected in these samples through the IFAT test and ELISA, nor were they found to be reactive in the RDT. Samples \#141, \#144, \#150 and \#156 were seroreactive against the $P$. malariae antigen and were positive in snPCR and qPCR assays. 18S rRNA Plasmodium sequences obtained from samples \#136 and \#156 showed 100\% identity to a P. malariae sequence (GU950655) previously deposited in GenBank. Comparison of the results from snPCR and qPCR, 48 samples $(87.27 \%$; 48/55) were positive through both techniques, while seven samples $(12.72 \% ; 7 / 55)$ were positive only through qPCR.

\section{Discussion and Conclusion}

Even with investments from several international agencies for research on vaccines, drugs and control measures, malaria is still considered to be one of the most important neglected diseases in the world, given the context of the populations that live in areas at risk of transmission of this disease. Because malaria is the parasitic disease with the highest mortality and morbidity in the human population in tropical and subtropical areas of the world, its eradication is an urgent matter (WHO, 2016). However, simian malaria is one of the factors that may constitute barriers to eradication of the disease around the world. It has been seen that unplanned urbanization that results in overlapping between urban areas and the wild environment enables interchange of vectors between these two environments and, consequently, interchange of pathogens. Thus, given that there may not be any biological barriers between human hosts and NHPs, simian malaria can be propagated beyond tropical forests. In this regard, monitoring of New World primate populations in relation to malaria is important, both for understanding how these parasites continue to circulate in nature and for identifying the real risk to the health of these animals through infection by Plasmodium sp. Thus, accurate diagnosis makes an important contribution towards knowledge of the circulation of Plasmodium sp. in NHP species in Brazilian biomes.

Although optical microscopy is the gold standard for diagnosing human malaria species, it presents relatively low sensitivity in cases of mixed infections and, especially, in cases of low levels of parasitemia (TANGPUKDEE et al., 2009). The latter is of importance in relation to blood samples from New World primates, which usually present chronic infections with low levels of parasitemia (AMERI, 2010), regardless of the animal species or the biome inhabited (CHINCHILLA et al., 2006; YAMASAKI et al., 2011). In the present study, optical microscopy did not present sensitivity of gold-standard level when compared to molecular tests, which showed higher sensitivity (DUARTE et al., 2008; YAMASAKI et al., 2011; BUENO et al., 2013). Additionally, experienced microscopists are currently only to be found in reference centers, thus making it difficult to diagnose simian malaria (BAIRD, 2009). In outbreaks of human malaria in Asia in the early 2000s, the etiological agent involved was misdiagnosed as $P$. malariae or $P$. falciparum; in reality, the agent was $P$. knowlesi, which is the zoonotic agent of simian malaria (SINGH et al., 2004).

Regarding the Plasmodium species, $P$. brasilianum/P. malariae are the species most commonly diagnosed in NHPs in the Americas (DEANE, 1992). Rapid diagnostic tests, for the most part, only specifically detect $P$. falciparum and $P$. vivax. In the present study, a WHO-approved RDT kit was used, which was standardized to identify one or more of the four species of Plasmodium that infect humans. Although there are many commercially available rapid diagnostic tests for diagnosing human malaria, there are currently no tests available for detecting Plasmodium species in 
NHPs. Trials have shown that antibodies to lactate dehydrogenase ( $\mathrm{pLDH})$, which enable detection of human malaria parasites such as $P$. falciparum and $P$. vivax, can also be used to detect $P$. knowlesi. However, it has been recommended that RDTs that were designed to detect human malaria should be used with great caution in primate blood samples. They should not be used as replacements for optical microscopy but, rather, have been recommended as secondary tests (AMERI, 2010). These results, along with those of Bueno (2012), are the first reports on the use of RDTs in Plasmodium research on whole-blood samples from New World primates. The low levels of parasitemia that are characteristic of NHP samples, makes the use of this type of test inappropriate.

In the present study, the number of animals that were found to be positive through molecular diagnosis was significantly higher than the number ascertained through direct (morphological) detection. After analysis on the results, the method that was chosen as the gold standard for the present study was snPCR, taking into account its sensitivity $(0.01$ parasites $/ \mu \mathrm{L})$ and reproducibility (RUBIO et al., 2002). In addition, snPCR allows species-specific diagnosis for the four most common Plasmodium species in humans (P. falciparum, P. vivax, P. malariae and $P$. ovale) in a single reaction, thus presenting lower costs.

It is worth mentioning that five microliters of DNA were used in the first reaction and two microliters of PCR product in the second reaction (undiluted), to increase the chances of making the band visible on the gel. This procedure differed from the original protocol. For samples with low levels of parasitemia, occurrences of false-negative results also need to be taken into account. This situation has been frequently reported by several authors, in the so-called "all or nothing phenomenon". From a practical point of view, several amplifications of the same sample may present divergent results, if the level of parasitemia is close to the detection threshold (BOONMA et al., 2007; YAMASAKI et al., 2011; FIGUEIREDO et al., 2015). Therefore, for samples with low degrees of parasitemia, more than one PCR assay is recommended, to obtain more accurate results (BOONMA et al., 2007; FIGUEIREDO et al., 2015). Although most studies have shown that PCR is more sensitive and specific for diagnosing malaria, there are limitations that may affect the accuracy of the method. In this regard, selection of suitable primers, the methods used for collection and storage of blood samples and the extraction methods may affect the performance of the technique (COLEMAN et al., 2006).

In contrast, none of the DNA samples extracted from NHP blood in the present study were positive through the LAMP technique. This technique was developed to be more sensitive than real-time PCR, since it uses six target sites within the DNA template. Although previous studies have noted that LAMP is very sensitive, with a detection threshold of up to 5 parasites $/ \mu \mathrm{L}$, the real-time PCR technique used in the present study was more sensitive, with detection of 0.5 parasite/ $\mu \mathrm{L}$ (GAMA et al., 2007), as was also the snPCR technique. Most protocols for LAMP have been standardized using clinical samples from human patients with the symptoms of clinical malaria (PATEL et al., 2013). According to the authors of the LAMP technique that was used in the present study, the standardized protocol has sensitivity similar to that of microscopy, but presents higher specificity (HAN et al., 2007).
In addition, the LAMP technique is still very expensive, since the kit is imported and not yet distributed in Brazil. The result showed that, at least for detection of Plasmodium in samples from New World primates, the technique was not sufficiently sensitive.

Regarding qPCR, its sensitivity was higher than the other tests (plasmid dilution of 0.5 parasite $/ \mu \mathrm{L}$ ), given that it presented the highest number of positive samples detected. It should also be noted that, due to the low levels of parasitemia, the majority of the positive samples showed a quantification coefficient $(\mathrm{Cq})$ greater than 35 cycles, thus corroborating the data regarding the low levels of parasitemia in these samples.

Because of the complex immune response to Plasmodium antigens, serological tests cannot be used for diagnosing malaria in humans (TANGPUKDEE et al., 2009) or in NHPs, in routine clinical assessments. In addition, such assays may not be useful for diagnosing severe malarial infection, because antibody production takes place over a period of time and, to reach a reasonable level of antibody production, the host needs to be constantly challenged through bits from infected mosquitos. In the present study, in relation to detection of anti-Plasmodium spp. antibodies, a cross-reaction was expected against $P$. falciparum and $P$. berghei antigens, both through IFAT and through ELISA. However, only four serum samples from Sapajus sp. were reactive, and only against antigens of $P$. malariae, which is a species similar to $P$. brasilianum. Thus, even the samples with presence of the parasite observed on microscope slides or with positive PCR results did not present detectable levels of antibodies against Plasmodium. These data are concordant with the results obtained by Duarte et al. (2006), who found that no serum samples from Callithrix $(\mathrm{n}=44)$ and Cebus apella $(\mathrm{n}=56)$, sampled in Savannah and Atlantic forest biomes, were reactive to the three antigens used ( $P$. falciparum, P. malariae and $P$. vivax), through IFAT. However, other authors have identified high antibody titers against $P$. brasilianum/P. malariae and $P$. vivax antigens, through IFAT, among captive New World primates in the state of São Paulo (YAMASAKI et al., 2011) and free-ranging primates in French Guiana (VOLNEY et al., 2002). It has also been reported in the literature that the ELISA test showed greater sensitivity for detecting antibodies in samples both from humans and from New World primates (VOLNEY et al., 2002; YAMASAKI et al., 2011). In this light, in the present study, standardization of this assay was attempted using soluble antigens of rhoptry proteins of $P$. falciparum (from culturing) and $P$. berghei (from parasitized erythrocytes from infected mice). Because of difficulty in obtaining red cells infected with $P$. vivax and $P$. malariae, since these two species are not kept in in vitro cultures and their levels of parasitemia in infected human patients is low, no antigens of these two Plasmodium species were used.

In NHPs, the levels of production of anti-Plasmodium spp. antibodies are even lower, and detection through serological methods is not efficient (DUARTE et al., 2006; YAMASAKI et al., 2011). Therefore, the difficulty in detecting antibodies in serum samples from New World primates infected with Plasmodium spp. is very evident. Animal Plasmodium antigens are commonly used in making serodiagnosis of human malaria because of cross-reactions between homologous species of Plasmodium (BOULOS et al., 1984). Even though some authors have stated that serodiagnosis can be used as a screening test to confirm exposure 
to current or former malaria infection (NARDIN et al., 1989; VOLNEY et al., 2002), the responses are often less expressive, even in endemic areas, and thus the degree of cross-reaction is also low. In immunochromatographic tests (rapid diagnostic tests) for detection of antibodies against Plasmodium spp., the sensitivity is also low (MURRAY et al., 2003; AMERI, 2010). Detection of anti-Plasmodium antibodies in primate serum samples from several Brazilian biomes showed low reactivity rates both in IFAT and in ELISA (DUARTE et al., 2006). The latter authors also searched for anti-Plasmodium spp. antibodies in serum samples from Callithrix and Sapajus (seroreactive species in the present study) in two different biomes (Cerrado and Atlantic Forest), and found that these NHP species were seronegative in the two serological tests (IFAT and ELISA).

Regarding the disagreement between molecular techniques and microscopy results, this finding has also been reported by other authors who analyzed blood samples from New World primates (DUARTE et al., 2008; YAMASAKI et al., 2011; FIGUEIREDO et al., 2015) and humans (COLEMAN et al., 2006; BOONMA et al., 2007). In general, PCR has been found to be more sensitive and specific than thick and thin-drop blood smears and RDT for both human (LIMA et al., 2016) and New World primates blood samples, particularly in cases of low levels of parasitemia or mixed infections (BROWN et al., 1992; MOODY, 2002; RUBIO et al., 1999).

In the present study, the presence of $P$. brasilianum/P. malariae was identified in New World primates in two municipalities on the island of São Luís, state of Maranhão, in the eastern Amazon region of Brazil. Furthermore, PCR (snPCR or qPCR) was confirmed as being the most sensitive technique for diagnosing Plasmodium in blood samples from New World primates. Whether snPCR or qPCR should be used will depend on the infrastructure of the laboratory and should take into account the importance of the results in relation to projects for reintroduction of endangered species and the risks of introduction of pathogens.

\section{Additional Information}

- Buffered methylene blue (1g of methylene blue medicinal powder, $1 \mathrm{~g}$ of $\mathrm{KH}_{2} \mathrm{PO}_{4}, 3 \mathrm{~g} \mathrm{Na} \mathrm{HPO}_{4}$ - the salts are mixed, $1 \mathrm{~g}$ of this mixture is withdrawn and $250 \mathrm{~mL}$ of distilled water);

- Buffered water (6g of anhydrous $\mathrm{Na}_{2} \mathrm{HPO}_{4}, 5 \mathrm{~g}$ of $\mathrm{KH}_{2} \mathrm{PO}_{4}$ and distilled water q.s.q to a 1 liter);

- PBS pH $7.2(130 \mathrm{mM} \mathrm{NaCl}, 2.7 \mathrm{mM} \mathrm{KCl}, 5.6 \mathrm{mM}$ $\mathrm{Na}_{2} \mathrm{HPO}_{4}, 1 \mathrm{KH}_{2} \mathrm{PO}_{4}, 0.8 \mathrm{mM} \mathrm{NaH}_{2} \mathrm{PO}_{4}$ );

- Anti-monkey IgG FITC-conjugation and anti-human IgG FITC (Sigma-Aldrich ${ }^{\circledR}$, St. Louis, Missouri, USA) - diluted 1:40 in Evans blue and PBS ( $\mathrm{pH} 9.2)$;

- Buffered glycerin $(9 \mathrm{~mL}$ of glycerin to $1 \mathrm{~mL}$ of carbonatebicarbonate solution, $\mathrm{pH}$ 9.6);

- PBS-Tween 20 pH $7.2(130 \mathrm{mM} \mathrm{NaCl}, 2.7 \mathrm{mM} \mathrm{KCl}$, $5.6 \mathrm{mM} \mathrm{Na}_{2} \mathrm{HPO}_{4}, 1 \mathrm{KH}_{2} \mathrm{PO}_{4}, 0.8 \mathrm{mM} \mathrm{NaH}_{2} \mathrm{PO}_{4}, 0.05 \%$ Tween 20);
- Homogenization medium pH 7.5 (0.25M Sucrose, 1mM EDTA, $5 \mathrm{mM}$ triethanolamine-HCL);

- $83 \%$ Ammonium Tris-Chloride (5 mL of Tris with $45 \mathrm{~mL}$ of $0.83 \%$ Ammonium Chloride);

- TBS-Tween 20 (0.1 M Tris, $0.1 \mathrm{M} \mathrm{NaCl}$ and $0.05 \%$ Tween 20).

\section{Acknowledgements}

The authors thank the staff of São Paulo Research Foundation (FAPESP) for the doctoral scholarship (grant no. 12/03961-9) and the research grant (no. 10/12820-4). They specially thank the staff of Sítio Aguahy (João and Maria) and CETAS of the Island of São Luís by supporting the work during the collection of samples. We would like to extend our gratitude to Dr. Roberto Rodrigues Veloso Junior (CETAS/MA/IBAMA/MM) for his support at all times. We also thank the Universidade Estadual do Maranhão for the support.

\section{References}

Aitken EH, Bueno MG, Dos Santos Ortolan L, Alvaréz JM, Pissinatti A, Kierulff MC, et al. Survey of Plasmodium in the golden-headed lion tamarin (Leontopithecus chrysomelas) living in urban Atlantic forest in Rio de Janeiro, Brazil. Malar J 2016; 15(1): 93. http://dx.doi.org/10.1186/ s12936-016-1155-3. PMid:26883507.

Altschul SF, Gish B, Miller W, Myers EW, Lipman DJ. Basic local alignment search tool. J Mol Biol 1990; 215(3): 403-410. http://dx.doi. org/10.1016/S0022-2836(05)80360-2. PMid:2231712.

Ameri M. Laboratory diagnosis of malaria in nonhuman primates. Vet Clin Pathol 2010; 39(1): 5-19. http://dx.doi.org/10.1111/j.1939165X.2010.00217.x. PMid:20456124.

Baird JK. Malaria zoonoses. Travel Med Infect Dis 2009; 7(5): 269-277. http://dx.doi.org/10.1016/j.tmaid.2009.06.004. PMid:19747661.

Boonma P, Christensen PR, Suwanarusk R, Price RN, Russell B, LekUthai U. Comparison of three molecular methods for the detection and speciation of Plasmodium vivax and Plasmodium falciparum. Malar J2007; 6(1): 124. http://dx.doi.org/10.1186/1475-2875-6-124. PMid:17868467.

Boulos M, Ceneviva AC, Shiroma M, Camargo ME, Castilho EA. Inquérito soroepidemiológico sobre malária em escolares de marabá, Pará. Rev Inst Med Trop São Paulo 1984; 26(1): 60-65. http://dx.doi. org/10.1590/S0036-46651984000100009. PMid:6463522.

Brasil. Ministério da Saúde. Manual de diagnóstico laboratorial da malaria [online]. 1. ed. Brasília: SVS; 2005. (Série A, Normas e Manuais Técnicos) [cited 2018 May 6]. Available from: http://www.saude.gov.br/svs

Brasil P, Zalis MG, Pina-Costa A, Siqueira AM, Bianco C Jr, Silva S, et al. Outbreak of human malaria caused by Plasmodium simium in the Atlantic Forest in Rio de Janeiro: a molecular epidemiological investigation. Lancet 2017; 5(10): e1038-e1046. PMid:28867401.

Brown AE, Kain KC, Pipithkul J, Webster HK. Demonstration by the polymerase chain reaction of mixed Plasmodium falciparum and $P$. vivax infections undetected by conventional microscopy. Trans $R$ Soc 
Trop Med Hyg 1992; 86(6): 609-612. http://dx.doi.org/10.1016/00359203(92)90147-5. PMid:1287912.

Bruce-Chwatt LJ. Essential malariology. 2nd ed. London: Heinemain Medical Books; 1985.

Bueno MG, Rohe F, Kirchgatter K, Di Santi SMF, Guimarães LO, Witte CL, et al. Survey of Plasmodium spp. in Free-Ranging Neotropical Primates from the Brazilian Amazon Region impacted by Anthropogenic Actions. EcoHealth 2013; 10(1): 48-53. http://dx.doi.org/10.1007/s10393-0120809-z. PMid:23404035.

Bueno MG. Pesquisa de Leishmania spp. e Plasmodium spp. em primatas neotropicais provenientes de regiöes de Mata Atlântica e Amazônia impactadas Por Açôes Antrópicas: investigação in situ e ex situ [tese]. São Paulo: Faculdade de Medicina Veterinária e Zootecnia, Universidade de São Paulo; 2012.

Chinchilla M, Guerrero OM, Gutiérrez G, Sánchez R. Presencia de Plasmodium brasilianum (Apicomplexa, Plasmodidae) en el mono congo (Alouatta palliata, Primates: Cebidae) de Costa Rica. Importancia epidemiológica en relación con el ser humano. Parasitol Latinoam 2006; 61(3-4): 192-196. http://dx.doi.org/10.4067/S0717-77122006000200018.

Ciceron L, Jaureguiberry G, Gay F, Danis M. Development of a Plasmodium PCR for monitoring efficacy of antimalarial treatment. J Clin Microbiol 1999; 37(1): 35-38. PMid:9854060.

Coleman RE, Sattabongkot J, Promstaporm S, Maneechai N, Tippayachai B, Kengluecha A, et al. Comparison of PCR and microscopy for the detection of asymptomatic malaria in a Plasmodium falciparum/vivax endemic area in Thailand. Malar J 2006; 5(1): 121. http://dx.doi. org/10.1186/1475-2875-5-121. PMid:17169142.

Deane LM. Studies on Simian Malaria in Brazil. Bull World Health Organ 1964; 31(5): 752-753. PMid:14278011.

Deane LM. Plasmodia of monkey and malaria eradication in Brazil. Rev Latinoam Microbiol Parasitol 1969; 11(2): 69-73. PMid:4980581.

Deane LM. Simian malaria in Brazil. Mem Inst Oswaldo Cruz 1992;87(3 Suppl 3): 1-20. http://dx.doi.org/10.1590/S0074-02761992000700001. PMid:1343676.

Doderer C, Heschung A, Guntz F, Cazenave JP, Hansmann Y, Senegas A, et al. A new ELISA kit which uses a combination of Plasmodium falciparum extract and recombinant Plasmodium vivax antigens as an alternative to IFAT for detection of malaria antibodies. Malar J 2007; 6(1): 19. http://dx.doi.org/10.1186/1475-2875-6-19. PMid:17313669.

Draper CC, Sirr SS. Serological investigations in retrospective diagnosis of malaria. BMJ 1980; 280(6231): 1575-1576. http://dx.doi.org/10.1136/ bmj.280.6231.1575. PMid:7000244.

Duarte AMRC, Malafronte RS, Cerutti CJ Jr, Curado I, Paiva BR, Maeda AY, et al. Natural Plasmodium infections in Brazilian wild monkeys: reservoirs for human infections? Acta Trop 2008; 107(2): 179-185. http://dx.doi.org/10.1016/j.actatropica.2008.05.020. PMid:18620330.

Duarte AMRC, Porto MAL, Curado I, Malafronte RS, Hoffmann EHE, Oliveira SG, et al. Widespread occurrence of antibodies against circumsporozoite protein and against blood forms of Plasmodium vivax, P. falciparum and P. malariae in Brazilian wild monkeys. J Med Primatol 2006; 35(2): 87-96. http://dx.doi.org/10.1111/j.1600-0684.2006.00148.x. PMid:16556295.

Fandeur T, Volney B, Peneau C, De Thoisy B. Monkeys of the rainforest in French Guiana are natural reservoirs for $P$. brasilianum/P. malariae malaria. Parasitology 2000; 120(1): 11-21. http://dx.doi.org/10.1017/ S0031182099005168. PMid:10726261.
Figueiredo MAP, Di Santi SMF, Figueiredo TAP, Machado RZ. Natural Plasmodium infection in neotropical primates in the Island of São Luís, state of Maranhão, Brazil. Rev Bras Parasitol Vet 2015; 24(2): 122-128. http://dx.doi.org/10.1590/S1984-29612015034. PMid:26154952.

Figueiredo MAP, Di Santi SMF, Manrique WG, André MR, Machado RZ. Identification of Plasmodium spp. in Neotropical primates of Maranhense Amazon in Northeast Brazil. PLoS One 2017; 12(8): e0182905. http:// dx.doi.org/10.1371/journal.pone.0182905. PMid:28796820.

Figueiredo MAP. Identificação de Plasmodium spp. em primatas neotropicais e em anofelinos em municípios da Ilha de São Luís, estado do Maranhão, Brasil [tese]. Jaboticabal: Faculdade de Ciências Agrárias e Veterinárias, Universidade Estadual Paulista "Júlio de Mesquita Filho"; 2015.

Gama BE, Silva-Pires FES, Lopes MNR, Cardoso MAB, Britto C, Torres $\mathrm{KL}$, et al. Real-time PCR versus conventional PCR for malaria parasite detection in low-grade parasitemia. Exp Parasitol 2007; 116(4): 427-432. http://dx.doi.org/10.1016/j.exppara.2007.02.011. PMid:17433301.

Han ET, Watanabe R, Sattabongkot J, Khuntirat B, Sirichaisinthop J, Iriko H, et al. Detection of four Plasmodium species by genus- and speciesspecific loop-mediated isothermal amplification for clinical diagnosis. J Clin Microbiol 2007; 45(8): 2521-2528. http://dx.doi.org/10.1128/ JCM.02117-06. PMid:17567794.

Hristov AD, Sanchez MC, Ferreira JJ, Lima GFMC, Inoue J, CostaNascimento MJ, et al. Malaria in pregnant women living in areas of low transmission on the southeast Brazilian Coast: molecular diagnosis and humoural immunity profile. Mem Inst Oswaldo Cruz 2014; 109(8): 10141020. http://dx.doi.org/10.1590/0074-0276140229. PMid:25494466.

Joyner C, Barnwell JW, Galinski MR. No more monkeying around: primate malaria model systems are key to understanding Plasmodium vivax liver-stage biology, hypnozoites, and relapses. Front Microbiol 2015; 6: 145. http://dx.doi.org/10.3389/fmicb.2015.00145. PMid:25859242.

Laemmli UK. Cleavage of structural proteins during the assembly of the head bacteriophage T4. Nature 1970; 227(5259): 680-685. http:// dx.doi.org/10.1038/227680a0. PMid:5432063.

Lalremruata A, Magris M, Vivas-Martínez S, Koehler M, Esen M, Kempaiah P, et al. Natural infection of Plasmodium brasilianum in humans: man and monkey share quartan malaria parasites in the Venezuelan Amazon. EBioMedicine 2015; 2(9): 1186-1192. http://dx.doi.org/10.1016/j. ebiom.2015.07.033. PMid:26501116.

Lima GFMC, Lucchi NW, Silva-Flannery L, Macedo-de-Oliveira A, Hristov AD, Inoue J, et al. Still searching for a suitable molecular test to detect hidden Plasmodium infection: a proposal for blood donor screening in Brazil. PLoS One 2016; 11(3): e0150391. http://dx.doi.org/10.1371/ journal.pone.0150391. PMid:26959994.

Machado RZ, McElwain TF, Suarez CE, Hines SA, Palmer GH. Babesia bigemina: isolation and characterization of merozoite rhoptries. Exp Parasitol 1993; 77(3): 315-325. http://dx.doi.org/10.1006/expr.1993.1089. PMid:8224087.

Moody A. Rapid diagnostic tests for malaria parasites. Clin Microbiol Rev 2002; 15(1): 66-78. http://dx.doi.org/10.1128/CMR.15.1.66-78.2002. PMid:11781267.

Murray CK, Bell D, Gasser RA, Wongsrichanalai C. Rapid diagnostic testing for malaria. Trop Med Int Health 2003; 8(10): 876-883. http:// dx.doi.org/10.1046/j.1365-3156.2003.01115.x. PMid:14516298.

Myjak P, Nahorski W, Pieniazek NJ, Pietkiewicz H. Usefulness of PCR for diagnosis of imported malaria in Poland. Eur J Clin Microbiol Infect 
Dis 2002; 21(3): 215-218. http://dx.doi.org/10.1007/s10096-001-06900. PMid:11957025.

Nardin EH, Arruda M, Cochrane AH, Nussenzweig RS. Sero-epidemiological studies of malaria in Indian tribes and monkeys of the Amazon basin of Brazil. Am J Trop Med Hyg 1989; 41(4): 379-385. http://dx.doi. org/10.4269/ajtmh.1989.41.379. PMid:2508499.

Parida M, Sannarangaiah S, Dash PK, Rao PV, Morita K. Loop mediated isothermal amplification (LAMP): a new generation of innovative gene amplification technique; perspectives in clinical diagnosis of infectious diseases. Rev Med Virol2008; 18(6): 407-421. http://dx.doi.org/10.1002/ rmv.593. PMid:18716992.

Patel JC, Oberstaller J, Xayavong M, Narayanan J, DeBarry JD, Srinivasamoorthy G, et al. Real-time loop-mediated isothermal amplification (RealAmp) for the species-specific identification of Plasmodium vivax. PLoS One 2013; 8(1): e54986. http://dx.doi.org/10.1371/journal. pone.0054986. PMid:23349994.

Perelman P, Johnson WE, Roos C, Seuánez HN, Horvath JE, Moreira MAM, et al. A molecular phylogeny of living primates. PLoS Genet 2011; 7(3): e1001342. http://dx.doi.org/10.1371/journal.pgen.1001342. PMid:21436896.

Rubio JM, Benito A, Berzosa PJ, Roche J, Puente S, Subirats M, et al. Usefulness of seminested multiplex PCR in surveillance of imported malaria in Spain. J Clin Microbiol 1999; 37(10): 3260-3264. PMid:10488189.

Rubio JM, Post RJ, van Leeuwen WM, Henry MC, Lindergard G, Hommel M. Alternative polymerase chain reaction method to identify Plasmodium species in human blood samples: the semi-nested multiplex malaria PCR (SnM-PCR). Trans R Soc Trop Med Hyg 2002;96(1 Suppl 1): 199-204. http://dx.doi.org/10.1016/S0035-9203(02)90077-5. PMid:12055839.

Sam-Yellowe TY. Rhoptry organelles of the Apicomplexa: their role in host cell invasion and intracellular survival. Parasitol Today 1996; 12(8): 308-316. http://dx.doi.org/10.1016/0169-4758(96)10030-2. PMid:15275182.

Santos LC, Curotto SMR, Moraes W, Cubas ZS, Costa-Nascimento MJ, Barros IR Fo, et al. Detection of Plasmodium sp. in capybara. Vet Parasitol 2009; 163(1-2): 148-151. http://dx.doi.org/10.1016/j.vetpar.2009.03.042. PMid:19411142.

Singh B, Bobogare A, Cox-Singh J, Snounou G, Abdullah MS, Rahman HA. A genus and species-specific nested polymerase chain reaction malaria detection assay for epidemiologic studies. Am J Trop Med Hyg 1999; 60(4): 687-692. http://dx.doi.org/10.4269/ajtmh.1999.60.687. PMid:10348249.

Singh B, Daneshvar C. Human Infections and Detection of Plasmodium knowlesi. Clin Microbiol Rev 2013; 26(2): 165-184. http://dx.doi. org/10.1128/CMR.00079-12. PMid:23554413.

Singh B, Sung LK, Matusop A, Radhakrishnan A, Shamsul SSG, CoxSingh J, et al. A large focus of naturally acquired Plasmodium knowlesi infections in human beings. Lancet 2004; 363(9414): 1017-1024. http:// dx.doi.org/10.1016/S0140-6736(04)15836-4. PMid:15051281.
Tangpukdee N, Duangdee C, Wilairatana P, Krudsood S. Malaria diagnosis: a brief review. Korean J Parasitol 2009; 47(2): 93-102. http:// dx.doi.org/10.3347/kjp.2009.47.2.93. PMid:19488414.

Tazi L, Ayala FJ. Unresolved direction of host transfer of Plasmodium vivax v. P. simium and P. malariae v. P. brasilianum. Infect Genet Evol 2011; 11(1): 209-221. http://dx.doi.org/10.1016/j.meegid.2010.08.007. PMid:20849978.

Towbin H, Staehelin T, Gordon J. Electrophoretic transfer of proteins from polyacrylamide gels to nitrocellulose sheets: procedure and some applications. Proc Natl Acad Sci USA 1979; 76(9): 4350-4354. http:// dx.doi.org/10.1073/pnas.76.9.4350. PMid:388439.

Trager W, Jensen JB. Human malaria parasites in continuous culture. Science 1976; 193(4254): 673-675. http://dx.doi.org/10.1126/science.781840. PMid:781840.

Volney B, Pouliquen J-F, De Thoisy B, Fandeur T. A sero-epidemiological study of malaria in human and monkey populations in French Guiana. Acta Trop 2002; 82(1): 11-23. http://dx.doi.org/10.1016/S0001706X(02)00036-0. PMid:11904099.

William T, Rahman HA, Jelip J, Ibrahim MY, Menon J, Grigg MJ, et al. Increasing incidence of Plasmodium knowlesi malaria following contro of P. falciparum and P. vivax malaria in Sabah, Malaysia. PLoS Negl Trop Dis 2013; 7(1): e2026. http://dx.doi.org/10.1371/journal.pntd.0002026. PMid:23359830.

World Health Organization - WHO. The use of malaria rapid diagnostic tests. Geneva: WHO; 2004.

World Health Organization - WHO. Basic malaria microscopy. Geneva: WHO; 2005.

World Health Organization - WHO. Malaria rapid diagnostic test performance: results of WHO product testing malaria RDTs: round 2. Geneva: WHO; 2009.

World Health Organization - WHO. World malaria report 2015 [online]. Geneva: WHO; 2015 [cited 2018 May 6]. Available from: http://www. who.int/malaria/publications/world-malaria-report-2015/report/en/

World Health Organization - WHO. World malaria report 2016 [online]. Geneva: WHO; 2016 [cited 2018 May 6]. Available from: http://apps. who.int/iris

Yamasaki T, Duarte AMRC, Curado I, Summa MEL, Neves DVDA, Wunderlich G, et al. Detection of etiological agents of malaria in howler monkeys from atlantic forests, rescued in regions of Sáo Paulo city, Brazil. JMed Primatol 2011; 40(6): 392-400. http://dx.doi.org/10.1111/j.16000684.2011.00498.x. PMid:21933192.

Zhang X, Lowe SB, Gooding JJ. Brief review of monitoring methods for loop-mediated isothermal amplification (LAMP). Biosens Bioelectron 2014; 61: 491-499. http://dx.doi.org/10.1016/j.bios.2014.05.039. PMid:24949822. 